\title{
SEJARAH PERTANIAN SAWAH LEBAK, PERAN PEREMPUAN DAN PANGAN KELUARGA DI KABUPATEN OGAN ILIR SUMATERA SELATAN
}

\author{
Yunindyawati, ${ }^{1}$ Titik Sumarti, MS ${ }^{2}$, Soeryo Adiwibowo ${ }^{2}$, Aida Vitayala ${ }^{2}$, \\ Hardinsyah $^{2}$ \\ 1Jurusan Sosiologi, FISIP Universitas Sriwijaya, email yunin.unsri@gmail.com \\ ${ }^{2}$ Departemen Ssiologi Pedesaan, Institut Pertanian Bogor
}

\begin{abstract}
Lowland agricultural fields have unique characteristics that only harvest once a year and planting process begins when the water has began to recede. The type of local rice planted is Pegagan. Pegagan has unique characteristics, such as high trees, paddy longer lifespan, pest resistant, and tougher rice grains. These plants favored local residents because the rice produced relatively hard so filling. Therefore, rice Pegagan be the ultimate local food for local people. When there is a green revolution policy to increase rice productivity, the type of rice Pegagan displaced and replaced by new IR 42 and Ciherang rice seedlings. Family food pattern shifted, including local livelihoods. This article presents an overview of the history of lowland rice farming, the role of women in agriculture and food family.
\end{abstract}

Keywords: History of lowland agriculture, role of women, family Food

\section{PENDAHULUAN}

Kegiatan pertanian (budidaya tanaman dan ternak) merupakan salah satu kegiatan yang dikenal di awal peradapan manusia. Para ahli prasejarah umumnya bersepakat bahwa pertanian pertama kali berkembang sekitar 12.000 tahun yang lalu dari kebudayaan di daerah "bulan sabit yang subur" di Timur Tengah, yang meliputi daerah lembah Sungai Tigris dan Eufrat terus memanjang ke barat hingga dae-

\begin{abstract}
ABSTRAK
Pertanian sawah lebak memiliki karakteristik unik dimana hanya panen sekali dalam setahun dan proses penanaman dimulai saat air mulai surut. Jenis padi yang ditanam merupakan padi lokal jenis pegagan dengan karakteristik batang pohon tinggi, umur padi lebih lama, tahan hama, dan bulir padi lebih keras. Tanaman ini disukai penduduk lokal karena beras yang dihasilkan relatif keras sehingga mengenyangkan. Oleh karena itu, padi Pegagan menjadi pangan lokal yang paling utama bagi masyarakat lokal. Keti$k a$ ada kebijakan revolusi hijau untuk meningkatkan produktivitas padi, maka semakin hari jenis padi Pegagan tergusur digantikan oleh bibit padi baru IR 42, Ciherang dan lainnya. Pola pangan keluarga pun bergeser, termasuk mata pencaharian penduduk lokal. Artikel ini menyajikan gambaran tentang sejarah pertanian padi lebak, peran perempuan dalam pertanian lebak serta pangan keluarga.
\end{abstract}

Kata kunci: sejarah pertanian lebak, peran perempuan, pangan keluarga rah Suriah danYordania. Kegiatan pertanian pun berkembang hingga saat ini di berbagai belahan dunia termasuk di Indonesia.

Indonesia adalah negara agraris yang memiliki lahan pertanian cukup luas serta mayoritas pekerjaan penduduknya adalah sebagai petani. Namun dalam periode 1983 sampai 1993 luas lahan pertanian mengalami penurunan dari 16,7 juta hektar menjadi 15,6 juta hektar, atau sekitar 110 ribu 
hektar pertahun. Penurunan tersebut terutama terjadi di Jawa, yang mempunyai implikasi serius dalam produksi komoditas pangan utama beras. Data BPS menunjukkan bahwa Jawa merupakan kawasan utama produksi di Indonesia. Pada tahun 2002 diperkirakan mencapai $56 \%$ dari total produksi beras nasional (Noor, 2007).

Menurut Pusat Analisis Sosial Ekonomi Pertanian Badan Litbang Pertanian (2006), sekitar 70\% petani padi merupakan buruh tani dan petani skala kecil, dengan ciri rata-rata skala penguasaan lahan usaha tani hanya 0,3 ha.mereka merupakan kelompok masyarakat miskin berpendapatan rendah. Umumnya mengalami keterbatasan akses terhadap berbagai layanan khususnya layanan pembiayaan usaha tani. Sekitar 60 persen dari petani padi merupakan net-consumer beras atau bersifat subsisten. Begitu juga dengan petani padi sawah lebak.

Pertanian padi sawah lebak merupakan salah satu jenis pertanian yang dilakukan di tanah rawa pasang surut. Penanaman hanya bisa dilakukan sekali dalam setahun pada saat air mulai surut setelah tergenang air selama musim penghujan. Propinsi Sumatera selatan merupakan propinsi yang memiliki lahan rawa lebak cukup besar yaitu mencapai 2,98 juta ha. Dari jumlah tersebut yang sudah dimanfaatkan sebanyak 368.690 hektar terdiri dari 70.908 hektar lebak dangkal, 129.103 hektar lebak tengahan dan 168.67 hektar lebak dalam (Noor 2007, Yunita 2011). Lahan lebak sangat potensial untuk pertanian terutama tanaman pangan.

Dua kabupaten yang memiliki luas lahan terbesar adalah Ogan Komering Ilir $(27,8 \%)$ dari total lahan lebak di Sumatera Selatan dan kabupaten Ogan Ilir $(20,6 \%)$ dari total lahan lebak di Sumatera Selatan. Lahan Rawa lebak dimanfaatkan untuk berbagai jenis per- tanian, terutama tanaman padi.

Tulisan ini menggambarkan sejarah perkembangan pertanian padi sawah lebak serta peran perempuan dalam pertanian di kabupaten Ogan Ilir dengan melakukan penelitian di Kecamatan Pemulutan Selatan.

\section{METODE PENELITIAN}

Metode penelitian menggunakan metode kualitatif, data digali melalui wawancara mendalam (in depth interview) dan FGD. Penelitian menggunakan metode sejarah lisan dengan melibatkan sebanyak 20 informan memberikan informasi terdiri dari tokoh adat, tokoh masyarakat, tokoh agama, warga masyarakat serta aparat pemerintah terkait. Penelitian berlangsung dari bulan Agustus 2012 hingga Maret 2013. Lokasi penelitian di kecamatan Pemulutan Selatan Kabupaten Ogan Ilir Sumatera Selatan.

\section{HASIL DAN PEMBAHASAN}

Petani padi sawah lebak telah menjalankan proses pertanian padi secara turun temurun dari jaman nenek moyang mereka. Mereka menanan padi lokal yang sering disebut padi pegagan. Jenis padi ini diakui sebagai benih padi yang tahan terhadap serangan hama dan burung. Ukuran padi relatif lebih tinggi dengan waktu tanam hingga panen yang lebih lama. Nasi yang dihasilkan dari padi pegagan lebih keras sesuai dengan kebiasaan makan penduduk yang menyukai nasi yang cenderung keras dan pera. Menurut mereka dengan nasi keras dan pera, perut mereka akan kenyang lebih lama jika memakan nasi yang lembut. Sejarah penanaman padi di Desa Ulak Aurstanding diceritakan oleh tokoh adat 
Sejarah Pertanian Sawah ... -Yunindyawati, dkk.

setempat.

Menurut informan Jml (63), masyarakat di Desa Ulak Aur Standing dari sejak jaman nenek moyang bekerja sebagai petani sawah lebak. Awalnya para petani menanam jenis padi tinggi sebagai benih lokal yang telah ditanam secara turun temurun, berikut penuturan informan.

Dari zaman nenek moyang mereka sudah menanam padi, tahun 1955 padi tinggi yang ditanam relatif berhasil. Sejak pengolahan melalui aret, di gebuk, jika yang ahli/tahu pertanian pasti tidak mau mengikuti, tetapi karena sudah banyak yang mengikuti, petani juga kehilangan semangat

Jenis padi tinggi yang ditanam penduduk pada tahun 1955 mengalami keberhasilan untuk memenuhi kebutuhan pangan masyarakat. Mereka memanen padi dengan cara ani-ani, karena padinya memiliki batang yang tinggi. Namun setelah menggunakan bibit baru yang relatif pendek cara memanennya berubah dengan menggunakan sabit kemudian di-gebukgebuk (dipukulkan dengan batu). Sebenarnya jika memahami pertanian sawah lebak, maka akan cenderung memilih padi lokal yang lebih sesuai dengan kondisi rawa. Namun karena tanaman baru dikenalkan oleh pemerintah dan banyak yang mengikutinya maka penduduk yang mempertahankan padi lokalmenjadi kehilangan semangat.

Petani padi sawah lebak pada sekitar tahun 1955-an memiliki kebiasaan dan tata cara dalam melakukan pertanian. Mereka masih sangat memegang nilai-nilai adat, dalam pengelolaan lahan persawahan. Sebagai contoh pada saat hendak memanen padi harus ada ritual adat sebelumnya. Begitu juga pada saat setelah panen padi. Berikut penuturan informan "Waktu dulu sebelum panen padi harus melakukan acara adat, pemilik sawah mengelilingi sawah mereka, sedekah dan memotong ayam bakar, waktu itu sekitar 1952-an..."

Sebelum pelaksanaan panen padi diadakan pesta sedekah dengan memotong ayam bakar untuk dibagikan kepada tetangga mereka. Pada saat padi hendak di potong (ani-ani) pemilik sawah mengelillingi areal persawahan mereka. Ritual ini dijalankan sebelum adanya intervensi pemerintah dalam proses penanaman padi. Namun seiring perubahan pola dan tata cara tanam, ritual ini mulai hilang. Bahkan hingga saat ini hanya segelintir penduduk yang masih melaksanakan adat tersebut dan biasanya mereka adalah para petani yang berusia tua.

Selain proses ritual tersebut, pada saat mengetam padi, ada beberapa hal yang perlu diperhatikan petani agar panen mereka berkah. Pada saat memperoleh dua atau 3 bagian sawah sudah diketam maka proses di berhentikan sejenak sekitar 2 sampai tiga hari. Pada saat proses mengetam para petani tidak boleh bersiul atau bicara terlalu keras agar padi yang dipetiknya bisa berkah.

Pelaksanaan panen padi juga tidak boleh dilaksanakan secara serempak. Setidaknya diboleh 4 bidang lahan yang bisa di panen secara bersamaan, dengan 4 kelompok petani pemanen. Hal ini dilakukan mengingat pada saat itu sistem tarikan masih berlaku. Sistem tarikan adalah sistem panen padi yang dikerjakan oleh 5-6 petani tanpa diupah, tetapi setelah selesai panen padi, petani tersebut (yang panen duluan/tarikan pertama) ikut membantu panen di tempat para petani yang membantu proses panen di ladangnya. Namun sistem ini sekarang sudah tidak berlaku lagi digantikan dengan sistem upahan perhari. Hal ini karena perubahan pola tanam dan karena tuntutan ekonomi. 


\section{Fase sebelum Revolusi Hijau}

Pada fase sebelum revolusi hijau, benih padi lokal yang ditanam adalah jenis pegagan, padi dengan karakteristik; tanamannya tinggi, bisa ditanam saat air pasang, tidak perlu pupuk buatan, tahan hama tikus dan burung. Informan mengatakan bahwa padi lokal lebih tahan hama jika dibandingkan dengan padi sekarang.

Sebenarnya secara umum, proses dan tahapan pengerjaan sawah lebak memiliki kesamaan antara padi lokal dan benih baru. Misalnya diawali dari macak-macak (mempersiapkan lahan, menyemai benih (nugal), memindahkan benih, menanam padi, menyiang dan memanen padi. Namun padi lokal memilki keunggulan-keunggulan.

Dari penjelasan tersebut diketahui bahwa padi lokal tidak menunggu air surut untuk bisa ditanam (sebagaimana padi bibit unggul yang harus menunggu air surut karena bibit pendek), sehingga saat musim tidak menentu tetap masih bisa panen karena masih kebagian air untuk bisa sampai panen. Berbeda halnya dengan padi bibit IR, karena saat tanam menunggu air surut,maka pada saat padi mulai keluar dan tidak ada hujan, sementara air genangan sudah

Selain itu, dari segi benih yang digunakan, banyak keunggulan benih jenis lokal dengan benih padi sekarang yang ditanam petani, berikut penuturan informan "Benih sekarang seperempat hektar hampir 2-3 kaleng kalau padi lokal dulu hanya perlu bibit satu kaleng, (1kaleng= $10 \mathrm{~kg}$ atau Rp 40.000,-), untuk menanam seperempat hektar..."

Setiap seperempat hektar memerlukan benih padi lokal sebanyak satu kaleng atau Rp. 40.000,-. Sementara untuk benih IR membutuhkan benih lebih banyak. Oleh karena itu input jenis tanaman padi baru relatif lebih mahal. Padi lokal untuk pembenihan lebih hemat jika dibandingkan dengan padi jenis baru.

Perubahan bibit yang ditanam oleh petani berakibat pada perubahan cara tanam, dan petani sering diatur oleh air untuk bertanam. Menanam padi baru harus menunggu kering, dan harus merumput, kondisi ini berbeda ketika menanam padi lama karena saat pasang sudah bisa menanam padi, tidak harus di bersihkan rumputnya terlebih dahulu. Membersihkan rumput akan memakan biaya sendiri utnuk pengupah buruh dan atau memerlukan tenaga ekstra dari petani untuk merumput. Selain itu para petani kemudian diatur oleh air, karena menanam padi harus menunggu saat lahan lebak surut dari genangan air. Untuk mempermudah memahami proses kegiatan penanaman padi dan keunggulannya pada fase sebelum penerapan revolusi hijau dapat dilihat pada tabel 1.

\section{Fase setelah Penerapan Revolusi Hijau}

Seiring perkembangan jaman, proses pertanian padi sawah lebak juga mengalami perubahan dari cara-cara lokal (konvensional) menuju ke arah penerapan teknologi dan inovasi pertanian. Hal ini dijelaskan oleh tokoh adat setempat yang mengatakan sejak dikenalkan cara pertanian oleh petugas pertanian, maka para petani mulai beralih ke caramodern (penggunaan pupuk buatan, alat-alat pertanian, insektisida, racun rumput, serta cara panen padi). Sebagai contoh para petani mulai memilih bibit unggul IR 42 (bibit unggul yang pertama kali diperkenalkan pemerintah kepada para petani) untuk menggantikan bibit lokal karena melihat ada petani yang menerapkan bibit tersebut berhasil dan produksinya meningkat.

Para petani berpindah ke bibit baru setelah melihat contoh nyata pening- 
Sejarah Pertanian Sawah ... -Yunindyawati, dkk.

Tabel 1. Kegiatan pertanian sebelum fase revolusi hijau

\begin{tabular}{|c|c|c|}
\hline No. & Jenis kegiatan pertanian & Keunggulan/manfaat \\
\hline 1. & $\begin{array}{l}\text { Ritual adat sebelum panen: memo- } \\
\text { tong ayam dan pemilik sawah } \\
\text { mengelilingi lahan yang hendak } \\
\text { dipanen. }\end{array}$ & $\begin{array}{l}\text { Sedekah kepada tetangga agar selamat dalam } \\
\text { proses panen dan mendapat keberkahan hasil } \\
\text { panen }\end{array}$ \\
\hline 2. & $\begin{array}{l}\text { Ritual dan aturan saat panen: di- } \\
\text { kerjakan oleh sekelompok petani 5- } \\
6 \text { orang, tidak boleh bersiul dan } \\
\text { berbicara keras saat memanen. Da- } \\
\text { lam sehari hanya boleh maksimal } 4 \\
\text { kelompok yang memanen padi. }\end{array}$ & $\begin{array}{l}\text { Tidak boleh bersamaan agar bisa saling mem- } \\
\text { bantu dan bergiliran memanen padi. }\end{array}$ \\
\hline 3. & $\begin{array}{l}\text { Sistem pengerjaan sawah: secara } \\
\text { gorong royong dengan sistem ta- } \\
\text { rikan (sistem giliran dalam } \\
\text { pengerjaan sawah lebak) }\end{array}$ & $\begin{array}{l}\text { Sistem tarikan dari menanam, mengolah mau- } \\
\text { pun memanen (bergantian siapa yang mengam- } \\
\text { bil tarikan awal akan membantu mengerjakan } \\
\text { petani lain yang membantunya). }\end{array}$ \\
\hline 4. & Racun hama/insektisida & Tidak memerlukan racun hama \\
\hline 5. & Pemeliharaan tanaman padi & $\begin{array}{l}\text { Lebih simpel karena tidak perlu merumput/ } \\
\text { menyiang rumput (rumput tidak banyak) }\end{array}$ \\
\hline 6. & $\begin{array}{l}\text { Bibit lokal Pegagan dan padi Siam } \\
\text { (masa tanam } 6 \text { bulan) }\end{array}$ & $\begin{array}{l}\text { Tahan hama (tikus dan burung), dan tahan } \\
\text { panas. }\end{array}$ \\
\hline 7. & $\begin{array}{l}\text { Air masih pasang (lahan masih } \\
\text { tergenang air) }\end{array}$ & $\begin{array}{l}\text { Bisa menanam padi saat air masih tinggi, tidak } \\
\text { perlu menunggu air sangat surut (karena bibit } \\
\text { lokal relatif tinggi). }\end{array}$ \\
\hline 8. & Jumlah benih lokal & $\begin{array}{l}\text { Lebih sedikit untuk satuan luas yang sama } \\
\text { dibanding benih baru }\end{array}$ \\
\hline 9. & Kualitas padi lokal hasil panen & Lebih keras dan mengenyangkan \\
\hline 10. & Kemungkinan gagal panen & $\begin{array}{l}\text { Relatif kecil karena lebih cepat menanam sehing- } \\
\text { ga masih kebagian air saat padi berbunga dan } \\
\text { berbulir hingga panen. }\end{array}$ \\
\hline
\end{tabular}

katan jumlah hasil panen padi dibanding menggunakan bibit padi lokal. Sejak dikenalkan padi kecil IR 42 kepada masyarakat oleh pemerintah dan petani merasakan keberhasilan jenis baru tersebut, maka sebagian besar masyarakat petani berpindah dan meninggalkan bibit lokal. Hal ini terjadi sekitar awal tahun 2000-an sebagian besar petani beralih ke padi kecil.

Kelebihan jenis IR tidak hanya dari sisi peningkatan jumlah panen tetapi juga harga jualnya yang relatif lebih mahal dari pada padi lokal. Menurut informan padi jenis Ir 42, untuk hasil panen biasanya lebih banyak dan harga jual juga lebih mahal, dibanding pada lama.

Selain itu ada faktor lain yang menyebabkan petani berpindah ke cara modern yaitu menurunnya produksi padi lokal karena pengaruh berkurangnya air sejak dibuat bendungan di hulu sungai yang memberikan dampak terhadap penurunan produksi padi sawah lebak pamulutan. Sekitar tahun 1990-an di daerah Belitang (daerah pertanian padi irigasi) dibangun bendungan untuk keperluan pengairan sawah. Hal ini menyebabkan air sungai Ogan dan Komering yang mengalir sampai ke wilayah desa, menyusut volume airnya. Bahkan semenjak dibangun bendungan hanya sungai $\mathrm{Og}$ - 
an yang mengalir dan bisa dimanfaatkan petani padi sawah lebak. Kondisi ini mengakibatkan tidak ada irigasi bagi pertanian sawah lebak. Saat tidak turun hujan pasti akan berakibat gagal panen, kondisi ini terjadi hingga kini.

Pembuatan bendungan tersebut bagi petani padi sawah lebak cenderung merugikan, karenanya informan juga mempertanyakan mengapa pemerintah kurang memperhatikan hal tersebut. Penurunan hasil padi dirasakan dari tahun ke tahun, hingga terakhir penuruan mencapai $60 \%$. Kondisi ini semakin mendorong para petani sawah lebak untuk memilih pertanian cara baru. Hal ini terjadi pada sekitar tahun 1995an.

Tanaman padi sawah lebak hanya bisa ditanami setahun sekali dan keberhasilannya sangat tergantung pada $\mathrm{cu}-$ rah hujan dan air sungai. Berhubung terdapat jenis sawah lebak, yakni lebak pematang, tengahan dan dalam maka penanaman padi dalam satu lahan tidak serentak tergantung jenis lebak dan surutnya air. Pada saat lebak pematang siap ditanami maka tengahan dan lebak dalam masih belum bisa di tanami karena masih tinggi kedalaman airnya. Umumnya penanaman hingga panen berlangsung mulai bulan April hingga bulan Semptember setiap tahunnya.

Baik sebelum revolusi hijau maupun setelah revolusi hijau, lahan rawa lebak hanya mungkin ditanami petani padi sawah lebak sekali dalam setahun. Menurut informasi petugas UPTD pertanian, masing-masing jenis lebak berbeda waktu masa tanam. Dalam kondisi iklim normal, lebak pematang mulai ditanami pada bulan April-Mei, lebak tengahan Mei-Juni dan lebak dalam JuliAgustus.

Penanaman padi unggul menunggu air surut, dan proses penanaman diawali dengan macak-macak (persiapan lahan) yaitu ketika posisi air sekitar 0,1 cm hingga $5 \mathrm{~cm}$. Bibit disemai 2-3 kali, dengan proses persemaian di rencam, di pecah dan disemai ke sawah. Proses ini dikenal sebagai sistem tugal. Sementara untuk persemaian dengan sistem ngapung, proses pembibitan menggunakan media. Medianya berupa rumput panjang (brondong) yang dipecah dan direndam kemudian dianyam, di atasnya diberi reamun (semacam rumput-rumput di lebak), tingginya sekitar sekilan, kemudian dipindahkan ke lahan yang agak basah atau ke galengan (dipecah) sambil menunggu air surut. Setelah air surut bibit siap ditanam.

Penerapan teknologi pertanian diintrodusir oleh pemerintah melalui dinas pertanian, dinas pekerjaan umum, badan perencanaan daerah dan badan penyuluhan dan ketahanan pangan daerah kabupaten Ogan Ilir. Menurut informasi kepala desa setempat, dinas pekerjaan umum memberi bantuan lewat program PNPM untuk perbaikan sarana fisik berupa cor beton untuk jalan (lebar sekitar $2 \mathrm{~m}$ ). Program ini berjalan dari tahun 2009 sampai 2011. Kemudian dinas pertanian pada tahun 2011 memberi bantuan jalan usaha tani dan memberi mesin perontok padi. Di tahun yang sama Bapeda juga memberikan bantuan 4 mesin traktor, 4 mesin pompa air, 4 mesin perontok padi dan 4 titik sumur bor. Pada tahun 2012 dibangun jaringan irigasi desa (JIDES) oleh dinas pertanian.

Selain bantuan teknis, dalam upaya peningkatan pengetahuan petani padi sawah lebak mengenai usaha pertanian, dinas pertanian membuat program dan bantuan diantaranya dibentuk sekolah lapangan pengelolaan terpadu (SLPTT). Tujuan dari program ini adalah pertama, terjadi peningkatan produksi, kedua, peningkatan produktivitas dan mutu, dan ketiga, peningkatan tanaman pangan. Melalui prog- 
Sejarah Pertanian Sawah ... -Yunindyawati, dkk.

ram ini para petani diberi materi cara bertani secara intens dengan membentuk kelompok tani. Materi yang disampaikan meliputi cara memupuk, meracun serangga, pembibitan dan lainnya. Selain itu, diberikan bantuan sarana produksi pertanian (saprodi) secara gratis berupa pupuk, benih, racun serangga, obat, serta bantuan sosial yang masuk ke rekening kelompok, bagi kelompok terpilih sebagai laboratorium lapangan.

Para petani diharuskan membentuk kelompok, dalam satu kelompok terdiri dari 25 orang petani dan maksimal luas lahan 25 hektar. Dalam satu desa akan dipilih satu kelompok sebagai laboratorium lapangan sebagai contoh bagi kelompok lain. Tujuannya adalah keberhasilan pertanian kelompok contoh ini akan ditiru oleh kelompok lain.

Semenjak diperkenalkan pupuk, benih baru, racun rumput, obat serangga, para petani mulai beralih ke caracara modern. Mereka tertarik setelah peningkatan produksi hasil panen dan harga padi yang lebih mahal dari pada padi jenis lokal. Namun biaya untuk produksi semakin meningkat dibanding dengan cara tradisional. Sebagai contoh pada waktu menggunakan padi lokal, mereka tidak menggunakan pupuk buatan, obat pestisida serta racun rumput, setelah mengunakan bibit baru, mereka harus mengeluarkan biaya lebih bannyak. Biaya benih, dari benih pilihan sendiri, menjadi membeli benih. Satu kantong benih seharga 40.000 rupiah. Kemudian untuk pupuk dua pikul seharga 280.000,- rupiah/ha. Untuk racun rumput dan racun hama perbotol 160.000,- rupiah.

Seorang petani dengan sawah seluas 2 hektar, harus mengeluarkan biaya pupuk dan racun sebesar 2.080.000,- rupiah. Belum lagi biaya upah untuk panen padi, sewa mesin perontok padi, mesin traktor untuk ngolah sawah dan lainnya. Hal ini menunjukkan bahwa masuknya teknologi dan inovasi pertanian disamping memeberikan peningkatn jumlah panen tetapi juga peningkatan biaya produksi. Bahkan tidak jarang petani justru harus berhutang dan membayarnya setelah panen untuk keperluan biaya produksi. Berbeda ketika mereka menanam padi lokal, mereka tidak memerlukan pupuk buatan dan racun hama, sehingga tidak membuat mereka terlilit hutang karena biaya produksi pertanian.

Namun hingga sekarang mayoritas petani menanam bibit baru (ciherang). Menurut informan dari dinas pertanian, penerapan bibit ciherang memungkinkan petani memanen padi lebih cepat karena usia padi ciherang tidak selama padi lokal (pegagan) yang mencapai 6 bulan. Dalam kondisi iklim yang tidak menentu akan terjadi kemarau panjang, air besar/pasang dan bahkan banjir. Karenanya kemungkinan keberhasilan menanam bibit lokal (pegagan) akan terpengaruh iklim yang pada akhirnya akan membuat gagal panen. Untuk lebih jelas mengenai beberapa manfaat penerapan inovasi dan teknologi pertanian dapat dilihat pada tabel 2.

\section{Potret Perempuan dalam Pertanian Padi Lebak dan Pangan Keluarga}

Perempuan dan pertanian memiliki kaitan erat. Dalam buku Sarinah (1947), presiden pertama Indonesia, Soekarno menyebutkan bahwa perempuanlah penemu ilmu pertanian yang pertama. Dalam sejarah manusia, sebelum dikenal berbagai jenis profesi, maka tani merupakan profesi paling awal yang dikenal manusia. Profesi tani menyediakan bahan pangan sehari-hari demi kelangsungan hidup manusia sehingga tani dapat dikatakan sebagai profesi 
awal dan vital manusia (Soeparto 2011).

Keterlibatan perempuan dalam kegiatan pertanian tidak hanya pada saat sebelum penerapan revolusi hijau tetapi juga setelah revolusi hijau meskipun ada pergeseran dan perubahan peran. Pada masa sebelum revolusi hijau perempuan memiliki peran dihampir seluruh proses pertanian padi sawah lebak. Mulai dari penyiapan lahan, pemilihan bibit, hingga ke proses pemanenan.

Setelah panen padi para perempuan menyisakan padi untuk dijadikan bibit untuk ditanam kembali. Biasanya mereka memilih padi yang bagus dengan cara menampi, menggunakan alat tampir dari bambu. Dengan digoyang-goyangkan akan terpisah antara padi yang bernas dan padi yang tidak berisi. Kemungkinan tumbuh yang $d i-$ tampi (padi bernas) cukup tinggi dibanding padi yang tidak ditampi. Padi ini kemudian disemai dengan cara ditugal, ditanam dengan menggunakan alu dari batang kayu. Setelah tumbuh agak tinggi dan air rawa surut maka padi dipindahkan ke lahan pertanian.

Selain itu perempuan juga terlibat dalam persiapan lahan dan menye- maikan padi, bahkan sebagian besar pekerjaan pertanian dilakukan oleh perempuan, kecuali pekerjaan yang berat.

Setelah lahan rawa agak surut, maka akan ditemui banyak rumput yang tumbuh selama air pasang (tumbuhan rawa). Oleh karena itu perlu dibesihkan terlebih dahulu sebelum ditanami. Mayoritas perempuan terlibat dalam kegiatan ini. Secara manual mereka membersihkan rumput tersebut namun setelah revolusi hijau dan dikenalkan dengan racun rumput, mereka menggunakan obat tersebut (jika memiliki kecukupan uang untuk membeli dan jika tidak maka dilakukan secara manual).

Setelah lahan bersih dari rumput maka para perempuan mengambil padi yang sudah ditugal (dibibit sebelumnya), dipindahkan ke tempat yang agak tinggi sebelum ditanam ke sawah rawa lebak. Begitu air rawa surut hingga tinggal $0,5-5 \mathrm{~cm}$ maka para perempuan banyak terlihat bertebaran di lahan menanam padi. Umumnya perempuan yang menanam padi sementara petani laki-laki hanya memikul bibit dari tempat pembibitan ke tempat perempuan menanan padi.

Tabel 2. Kegiatan pertanian setelah revolusi hijau

\begin{tabular}{|c|c|c|}
\hline No. & Jenis kegiatan pertanian & Keunggulan/manfaat \\
\hline 1. & Penggunaan bibit unggul & Lebih cepat panen/waktu lebih singkat \\
\hline 2. & Pemakaian pupuk & $\begin{array}{l}\text { Meningkatkan kesuburan tanaman se- } \\
\text { hingga produksi meningkat }\end{array}$ \\
\hline 3. & Pemakaian obat serangga & $\begin{array}{l}\text { Mengurangi bahkan membasmi serangga } \\
\text { pengganggu tanaman padi }\end{array}$ \\
\hline 4. & $\begin{array}{l}\text { Penggunaan traktor untuk mengolah la- } \\
\text { han }\end{array}$ & $\begin{array}{l}\text { Mempercepat pekerjaan menyiapkan la- } \\
\text { han siap tanam }\end{array}$ \\
\hline 5. & $\begin{array}{l}\text { Pemanfaatan mesin perontok padi } \\
\text { (grentek) }\end{array}$ & Mempercepat proses panen \\
\hline 6. & Pembentukan kelompok tani & $\begin{array}{l}\text { Media untuk mendapatkan bantuan dan } \\
\text { informasi pertanian }\end{array}$ \\
\hline 7. & $\begin{array}{l}\text { Berbagai program pendukung pertanian } \\
\text { dari berbagai instansi pemerintah }\end{array}$ & $\begin{array}{l}\text { Membantu memecahkan permasalahan } \\
\text { pertanian }\end{array}$ \\
\hline 8. & $\begin{array}{l}\text { Harga jual padi serta produktivitas jenis } \\
\text { unggul }\end{array}$ & $\begin{array}{l}\text { Lebih mahal serta hasil lebih banyak per- } \\
\text { satuan luas }\end{array}$ \\
\hline
\end{tabular}


Sejarah Pertanian Sawah ... -Yunindyawati, dkk.

Tabel 3. Peran perempuan dalam kegiatan pertanian sebelum dan setelah revolusi hijau

\begin{tabular}{|c|c|c|c|}
\hline No. & Jenis kegiatan & Sebelum revolusi hijau & Setelah revolusi hijau \\
\hline 1. & Pemilihan bibit & $\begin{array}{l}\text { Perempuan menampi padi } \\
\text { untuk dijadikan bibit }\end{array}$ & $\begin{array}{l}\text { Mayoritas petani membeli, } \\
\text { sedikit perempuan yang men- } \\
\text { ampi padi untuk bibit }\end{array}$ \\
\hline 2. & $\begin{array}{l}\text { Penyemaian bibit } \\
\text { (nugal) }\end{array}$ & $\begin{array}{l}\text { Menyemai, menugal dil- } \\
\text { akukan oleh perempuan }\end{array}$ & $\begin{array}{l}\text { Menyemai, menugal dilakukan } \\
\text { oleh perempuan dibantu laki- } \\
\text { laki }\end{array}$ \\
\hline 3. & Pemindahan bibit & $\begin{array}{l}\text { Dilakukan oleh perempuan, } \\
\text { laki-laki memikul bibit }\end{array}$ & $\begin{array}{l}\text { Dilakukan oleh perempuan, } \\
\text { laki-laki memikul bibit }\end{array}$ \\
\hline 4. & Penanaman bibit & Dilakukan perempuan & Dilakukan perempuan \\
\hline 5. & $\begin{array}{l}\text { Pembersihan } \\
\text { rumput }\end{array}$ & $\begin{array}{l}\text { Dilakukan perempuan secara } \\
\text { manual dibantu laki-laki }\end{array}$ & $\begin{array}{l}\text { Dilakukan laki-laki dengan } \\
\text { menggunakan racun rumput, } \\
\text { perempuan sedikit terlibat }\end{array}$ \\
\hline 6. & Pemanenan padi & $\begin{array}{l}\text { Dilakukan oleh perempuan } \\
\text { dengan menggunakan ani-ani } \\
\text { (ketam) sistem tarikan }\end{array}$ & $\begin{array}{l}\text { Perempuan menggunakan } \\
\text { sabit yang mengoperasikan } \\
\text { mesin grentek mayoritas laki- } \\
\text { laki (sistem upahan/bawon) }\end{array}$ \\
\hline 7. & Pemupukan & $\begin{array}{l}\text { Tidak memerlukan pupuk bu- } \\
\text { atan }\end{array}$ & $\begin{array}{l}\text { Perlu pupuk buatan yang } \\
\text { memupuk para laki-laki }\end{array}$ \\
\hline 8. & $\begin{array}{l}\text { Ritual sebelum } \\
\text { panen }\end{array}$ & $\begin{array}{l}\text { Perempuan menyiapkan ma- } \\
\text { kanan untuk keperluan ritual }\end{array}$ & Tidak ada ritual \\
\hline 9. & Ritual saat panen & $\begin{array}{l}\text { Perempuan berkelompok } \\
\text { memanen padi, menyiapkan } \\
\text { bekal makanan }\end{array}$ & Tidak ada ritual kelompok \\
\hline
\end{tabular}

Secara umum pekerjaan perempuan di pertanian sawah lebak tidak banyak perubahan dan perbedaan antara sebelum dan setelah revolusi hijau. Perbedaan menyoloknya terdapat pada pemilihan bibit, yang semula seluruh bibit dipilih dan dipilah oleh para perempuan sekarang hampir semua tergantung pada bibit dari membeli. Namun masih ada juga petani yang menggunakan bibit lokal maupun bibit unggul hasil panen yang dipilih untuk ditanam kembali. Selain itu pada saat belum dikenalkan proses pemanenan menggunakan sabit, para perempuan memanen dengan menggunakan ani-ani (mengetam). Setelah proses panen menggunakan sabit dan mesin grentek maka peran perempuan terkurangi. Pengoperasi mesin grentek umumnya laki-laki meskipun banyak juga perempuan telah bisa menggunakan alat ini. Untuk melihat peran perempuan sebelum dan setelah revolusi hijau dapat dilihat pada tabel 3 .

Peran perempuan dalam pertanian tersebut memberi kontribusi bagi ketersediaan pangan keluarga berupa padi. Selain di bidang pertanian padi, peran perempuan dalam pemenuhan pangan keluarga dilakukan dengan melakukan diversivikasi pekerjaan. Diversifikasi ini disesuaikan dengan pengetahuan, kemampuan serta kondisi lingkungan. Pengetahuan dan kemampuan menenun songket dimanfaatkan untuk menambah penghasilan keluarga untuk memenuhi kebutuhan pangan. Mereka juga memiliki pengetahuan tentang jenis-jenis tanaman yang aman dikonsumsi yang berada di lingkungan sekitar untuk pangan keluarga seperti buah telepuk, gondang dan tumbuhan lokal lainnya. Kegiatan menenun dilakukan oleh perempuan saat tidak ada pekerjaan sawah atau ketika musim 
Tabel 3. Peran perempuan dalam kegiatan pertanian sebelum dan setelah revolusi hijau

\begin{tabular}{|c|c|c|c|}
\hline No. & Jenis kegiatan & Sebelum revolusi hijau & Setelah revolusi hijau \\
\hline 1. & Pemilihan bibit & $\begin{array}{l}\text { Perempuan menampi padi } \\
\text { untuk dijadikan bibit }\end{array}$ & $\begin{array}{l}\text { Mayoritas petani membeli, } \\
\text { sedikit perempuan yang men- } \\
\text { ampi padi untuk bibit }\end{array}$ \\
\hline 2. & $\begin{array}{l}\text { Penyemaian bibit } \\
\text { (nugal) }\end{array}$ & $\begin{array}{l}\text { Menyemai, menugal dil- } \\
\text { akukan oleh perempuan }\end{array}$ & $\begin{array}{l}\text { Menyemai, menugal dilakukan } \\
\text { oleh perempuan dibantu laki- } \\
\text { laki }\end{array}$ \\
\hline 3. & Pemindahan bibit & $\begin{array}{l}\text { Dilakukan oleh perempuan, } \\
\text { laki-laki memikul bibit }\end{array}$ & $\begin{array}{l}\text { Dilakukan oleh perempuan, } \\
\text { laki-laki memikul bibit }\end{array}$ \\
\hline 4. & Penanaman bibit & Dilakukan perempuan & Dilakukan perempuan \\
\hline 5. & $\begin{array}{l}\text { Pembersihan } \\
\text { rumput }\end{array}$ & $\begin{array}{l}\text { Dilakukan perempuan secara } \\
\text { manual dibantu laki-laki }\end{array}$ & $\begin{array}{l}\text { Dilakukan laki-laki dengan } \\
\text { menggunakan racun rumput, } \\
\text { perempuan sedikit terlibat }\end{array}$ \\
\hline 6. & Pemanenan padi & $\begin{array}{l}\text { Dilakukan oleh perempuan } \\
\text { dengan menggunakan ani-ani } \\
\text { (ketam) sistem tarikan }\end{array}$ & $\begin{array}{l}\text { Perempuan menggunakan } \\
\text { sabit yang mengoperasikan } \\
\text { mesin grentek mayoritas laki- } \\
\text { laki (sistem upahan/ bawon) }\end{array}$ \\
\hline 7. & Pemupukan & $\begin{array}{l}\text { Tidak memerlukan pupuk bu- } \\
\text { atan }\end{array}$ & $\begin{array}{l}\text { Perlu pupuk buatan yang } \\
\text { memupuk para laki-laki }\end{array}$ \\
\hline 8. & $\begin{array}{l}\text { Ritual sebelum } \\
\text { panen }\end{array}$ & $\begin{array}{l}\text { Perempuan menyiapkan ma- } \\
\text { kanan untuk keperluan ritual }\end{array}$ & Tidak ada ritual \\
\hline 9. & Ritual saat panen & $\begin{array}{l}\text { Perempuan berkelompok } \\
\text { memanen padi, menyiapkan } \\
\text { bekal makanan }\end{array}$ & Tidak ada ritual kelompok \\
\hline
\end{tabular}

pasang. Pada musim ini mereka kebanyakan menenun songket karena air menggenangi sawah sehingga tidak ada aktivitas pertanian. Dari kegiatan menyonket mereka memperoleh penghasilan untuk memenui kebutuhan pangan keluarga seperti membeli lauk, sayur gula dan juga kebutuhan anak sekolah.

\section{SIMPULAN}

Pertanian padi sawah lebak memiliki sejarah perkembangan tersendiri, diawali dari pertanian sederhana dengan karakteristik unik dimana hanya panen sekali dalam setahun dan proses penanaman dimulai saat air mulai surut serta menggunkan teknik sederhana berdasarkan pengalaman turun temurun. Jenis padi yang ditanam merupakan padi lokal jenis pegagan dengan karakteristik batang pohon tinggi, umur padi lebih lama, tahan hama, dan bulir padi lebih keras. Tanaman ini disukai penduduk lokal karena beras yang dihasilkan relatif keras sehingga mengenyangkan. Oleh karena itu, padi Pegagan menjadi pangan lokal yang paling utama bagi masyarakat lokal. Setelah adanya intervensi kebijakan revolusi hijau untuk meningkatkan produktivitas padi, maka semakin hari jenis padi Pegagan tergusur digantikan oleh bibit padi baru IR 42, Ciherang dan lainnya. Pola pangan keluarga pun bergeser, termasuk mata pencaharian penduduk lokal. Pola pangan keluarga yang semula mengkonsumsi padi lokal pegagan sebagai pangan subsisten berubah menjadi padi jenis baru dan dimanfaatkan untuk kebutuhan pasar. 
Sejarah Pertanian Sawah ... -Yunindyawati, dkk.

Akibatnya introdusir teknologi pertanian mengurangi peran perempuan dalam kegiatan pertanian sawah lebak. Karena semakin tergusur maka perempuan mengoptimalisaikan pengetahuan dan keahlian mereka untuk memenuhi kebutuhan pangan dan menambah pendapatan keluarga.

Mengingat peran perempuan dalam pemenuhan pangan keluarga sangat penting maka perlu kiranya memberikan peluang berusaha pada perempuan untuk menambah penghasilan keluarga dengan berbasis pada pengetahuan dan keahlian mereka. Dengan modal pengetahuan dan keahlian mereka maka diharapkan akan mengoptimalkan kemampuan mereka menambah penghasilan dan memenuhi kebutuhan pangan keluarga. peluang tersebut bisa dilakukandengan memberikan stimulus berupa modal usaha maupun kesempatan meningkatkan ketrampilan dengan memeberikan tambahan pengetahuan sehingga mereka bisa mengakses kebutuhan pasar. Perlu juga memikirkan jaringan pemasaran sehingga mereka bisa memasarkan produk kepada konsumen yang lebih luas.

\section{DAFTAR PUSTAKA}

Denzin, N.K. dan Y.S. Lincoln. 2009. Handbook of Qualitative Research. Edisi Baha- sa Indonesia. Pustaka Pelajar. Yogyakarta. Indonesia.

Ellis, Frank. 2000. Rural livelihoods and Diversity in Developing Countries. New York: Oxford University Press.

Fauzi, Noer, 1999. Petani dan Penguasa Dinamika Perjalanan Politik Agraria Indonesia. Yogyakarta: Insist, KPA dan Pustaka Pelajar.

Majalah Pangan edisi 2010.

Noor, Muhammad, 2007. Rawa Lebak Ekologi, Pemanfaatan, dan Pengembangannya. Jakarta: PT RajaGrafindo Persada.

Redfield, Robert, 1982. Masyarakat Petani dan Kebudayaan. Terjemahan the Little Community, Peasant Society and Culture. Jakarta: CV Rajawali.

Ritzer, G dan D.J. Goodman. 2004. Teori Sosiologi Modern, edisi ke-6. Terjemahan: Modern Sociological Theory, $6^{\text {th }}$ Edition. Prenada Media. Jakarta Indonesia. 788 hal.

Sugiono. 2009. Metodologi Penelitian Kualitatif. Bandung: Alfabeta

Suharjo dkk. 2006. Pangan, Gizi dan Pertanian. Jakarta: UIP

Taradila, S A Adha. 2010. “Analisis Peran gender Dalam Pencapaian Ketahanan Pangan Rumah Tangga Petani di Kabupaten Konawe Selatan Propinsi Sulawesi Tenggara". Disertasi. IPB

Wahono, Francis dkk. 2005. Pangan Kearifan Lokal dan Keanekaragaman Hayati. Yogyakarta: Cindelaras.

Yunita. 2011. "Strategi Peningkatan Kapasitas Petani Padi Sawah Lebak menuju Ketahanan Pangan Rumah Tangga di Kabupaten Ogan Ilir dan OKI Propinsi Sumatera Selatan". Disertasi. IPB 